\title{
PROPHETIC AND ENIGMATIC IN ZVIAD GAMSAKHURDIA'S POETRY
}

\begin{abstract}
Nana Kiria, Master, Doctoral student, Teacher / Senior Lecturer / Consultant of the National Center for Professional Development of Teachers, Tbilisi No. 1 Experimental Public School, Tbilisi, Georgia DOI: https://doi.org/10.31435/rsglobal_conf/25122020/7315
\end{abstract}

Abstract. Even a glance at Zviad Gamsakhurdia's work shows that he has experienced a long creative burn, he is extremely strong in worldviews and eternal, unchanging, even strangely calm, but thematically changeable.

In his work, the arousal of feelings and the veil of thought are harmoniously combined. When the register of such harmony is very high, elements of prophethood appear in Zviad Gamsakhurdia's work and it must be said that his prophecy is infallible and skillfully placed in the artistic mold. In his poetry there is a skillfully blended vague allegory conveyed with a premeditated intent, something between mediocre openness and obscure, transparent and obscure. It can be boldly said that Zviad Gamsakhurdia is a master of enigmatic poetry.

The aim of the research is to critically analyze the poetry of the great Georgian figure, thinker and writer Zviad Gamsakhurdia (from a prophetic and enigmatic point of view).

The method is comparative. The merits and weaknesses of Zviad Gamsakhurdia's works can be seen in comparison, more - the first.

Research result - Prophecy by Zviad Gamsakhurdia is the biggest secret of life. Both his enigma and prophecy stem from bottomless freedom.

The poem with the conditional title "Probably God Himself" is one of the best in Zviad Gamsakhurdia's work. Here the arousal of the senses and the veil of thought are harmoniously merged with one another. When the register of such harmony is very high, elements of prophethood appear in the work of Zviad Gamsakhurdia and it must be said that his prophecy is infallible and skillfully placed in the artistic form. In addition, there should be a feeling of total loneliness, which adds to the conviction of his verses:

The eyes are always on you,

Lord, tempt me with a drinking.

You are the Father of all, caring for the sons,

Lord, tempt me with this drink.

Thy kingdom come, not me,

You yourself are the will, the bearer of the truth,

I have to take the burden of neighbor,

Have mercy on me, son of David!

(1. Z. Gamsakhurdia, father)

The protagonist knows exactly that he must drink the "drink" to lay the crown of martyrdom. Its meaning is clearly prophetic. How these lines resemble the words of Christ shouting in the Garden of Gethsemane. When it is said that a prophet addresses the cosmos with a message or vice versa, we think that with them it has no function and in the earthly dimension it cannot be accounted for. The conclusion from this is that beyond the prophetic time, time is given to it as a whole and not in the past, present or future.

This is the highest peak of prophecy, where the full picture of the future is achieved. The protagonist declares that he will have to repeat Christ's Golgotha in the face of envy and enmity, that he will be betrayed, and that he will be crowned a martyr.

The prophetic qualities of poetry traits were known in ancient Greece. In particular, Aristotle noted that the task of the poet was not to speak of what existed, but of what could or could have happened with his possibilities or inevitability (2. Aristotle, Poetics). We should also add that Zviad Gamsakhurdia's poetry is enigmatic, which is due to his highly intellectual writing style, which can be said to be over-intellectual poetry, which is conveyed with complex metaphorical thinking and needs to be explained. The prophetic and the enigmatic in his poetry are intertwined in such a way that often special observation is required to distinguish it and make it clear.

It is not surprising that Eliso Virsaladze's art inspires you, however, the exact perception and interpretation of her (also in verse) is not for everyone. It implies great intellectual resources and mastery of laconic style. A virtuoso work performed with an etude string instrument - Capriccio is a 
very dynamic and free musical play. It gives the poet an impression of the ancient world (Styx water; Charon), the Old Testament (Lebanon, Cherubim) and the prophetic (crown of torture). The Old and New Testaments are transferred directly to the furnace of antiquity and lead to the prophetic ending, where the last verse reminds us not only of a biblical parallel but also of the meaning of our own future. Schematically it can be represented as follows: (enigmatic part) Ancient Myth and Art> Old and New Testaments> (Prophethood) to reach the crown of martyrdom, the crown of mankind's longing - Christ and its allusion to his own destiny.

Every musical tone conveyed by Eliso Virsaladze with genius, a virtuoso musical play of a changeable nature, is in line with the pathos of the verse, and vice versa:

... and the star-born myth.

The black moons were falling down

To marble sky.

A whirlwind nestled in the strings.

In purple arches

Seemed your face

The most severe curse:

A whirlwind of turbulent thoughts like water of Styx,

Charon's shock,

Lebanon Fire -

And again - cherubim brilliance

Torture Crown.

(3. Z. Gamsakhurdia, CAPRICCIO)

It is difficult to say how poets can imagine the future. This is a study of various fields of science because many things are incomprehensible. Do poets possess certain qualities of a medium? Does the word uttered by them as a sacral element somehow affect the future? In Zviad Gamsakhurdia's poetry we can single out two facts of prophecy: first, the poet foretells a socio-political event before us - it will be an economic formation, a revolution, the start of a civil war, a natural disaster and so on; Secondly, the poet foretells the fate of other people and his personal life, first of all, about leaving this worldly life.

The idea that the poet was not merely poems writer, but a prophet committed to reaching the hearts of the people, dates back to the 19th century.

When Ilya, Vaja and Akaki talk about their connection with God and the leadership of the nation, they mean mystical prophecy. Ilia Chavchavadze stands out especially in this respect. The title of the poem is not accidental either. He states in direct text:

... not only for the sweet voice

Sent me Heaven to the Kingdom.

The sky establishes and the nation grows me,

Earthly and heavenly;

I speak to God for him,

To lead the nation.

(4. I. Chavchavadze, poet)

In the twentieth century, indeed, this function of the poet manifests itself in society. There were Mukhran Machavariani, Ana Kalandadze. Murman Lebanidze, in whose work this issue is deeply studied. To one degree or another, every true poet has prophetic abilities. The new century and the new millennium will prove it many times over. The mystification of prophecy is very tempting, but it requires more scientific study.

One of the main aims of poetry is to convey global and local information through various methods. This goal involves a cohesive reception - the reader as a co-author. The author himself as a creative unit is not self-sufficient. In modern culture, the idea of the communicative nature provides many interesting patterns for the development of an artist's creativity. Internal dialogue recognizes the creative nature of creativity, its aesthetic sense. The act of a work of art implies from the very beginning the connection of the poet with the macrocosm, and they transmit the received information in a language understandable for man to the modern and future generations. Perhaps they themselves send certain messages to the cosmos about the origin and nature of man after existence on earth after existence, which remains open to the present day (5. Chris Frist, Using Internal Dialogue to Achieve Multifaceted Effects).

"Dedication" is a sonnet in which the prophetic and the enigmatic are intertwined, but the poet formulates the utterance in a way that it turns into an untimely fog, but without a dizziness, it invites 
you to think. The fact that he avoided the situation of poem-puzzle at this time once again indicates the mastery of the poet:

Reverse lighting beam hidden

Joined the collection of weeping faces

How the lights and shadows of the night make the mountain think,

Visit the Altar of the Soul now another roll.

The Grail Tower can be seen in the distance, board-cracked,

Pallas Athena, roamed a carefree in the field of wisdom

"Black raven on the head of Asia" and faded

Surrounded by the dirty cartwheel of demons ...

(6. Zviad Gamsakhurdia, Dedication, Sonnet)

In this regard, we can assume that the poetry of the poet-prophet is characterized not only by a communicative function, but also by a meta-communicative or comprehensive function, which is intended for the widest possible audience, including from the future to the past and vice versa. The term can be a philosophical term and becomes its quintessence in the discursive analysis of creativity and it defines the main vectors of the poetic messages of prophecy.

In the poem-trilogy "Elegy of Zion" with the ascension of the Messiah and the arrogance of the hidden devils reminds us of the valley of Yin and Yang with the worldly good and evil and the path of poetry towards them, poetry plays the role of bringing relief here. How skillfully blended is a vague allegory conveyed by a premeditated, something of a middle ground between openness and obscurity, transparency and ambiguity. It can be boldly said that Zviad Gamsakhurdia is a master of enigmatic poetry:

The Messiah arose, and the arches were broken

Wild horserace in this ocean of joy!

The poetry of relief is the path of the companions,

How rabies is hidden from the devil!

(7. Zviad Gamsakhurdia, Elegy of Sioni, I)

The comparison of Zviad Gamsakhurdia with the mystery of the secret supper of his personal future is a sample of his dizzying eschatological imagination, which neither more nor less renders with his own blood.

The public drama there is transformed into his personal tragedy. And why did this happen? Was it not the inevitability of a ruthless and destructive fate that haunted the poet like a ghost? It has long been known that the main themes of poetry are love and death. It is clear from Gamsakhurdia's work that he wrote about love and death, but he wrote very accurately and measuredly:

The flames ignite flame

Lightning strikers on the air,

The seconds go by for years

Angels of sorrow sing

If I steal goodness why.

(8. Zviad Gamsakhurdia, torture of seconds)

Halolike strings

If the diadem of fortune

The tunes of the end

Would come peacocks.

(9. Zviad Gamsakhurdia, Kvabtakhevi Elegy)

He felt the end of his earthly existence and the universal recognition and immortality of the imminent after death. All his tragic and prophetic expressions came true.

\section{REFERENCES}

1. Z. Gamsakhurdia, Father, Cosmic Liturgy, 2014, p. 80

2. Aristotle, Poetics, Translator - Sergi Danelia, 2019. p.18

3. Z. Gamsakhurdia, CAPRICCIO, Cosmic Liturgy, 2014, p. 28

4. I. Chavchavadze, poet, Tb. 1860.

5. Chris Frist, "Using Internal Dialogue to Achieve Multiple Effects," Criss Freese- Using Internal Dialogue to Achieve Multiple Effects, 2016.

6. Zviad Gamsakhurdia, Dedication, Sonnet, Cosmic Liturgy, 2014, p. 25.

7. Zviad Gamsakhurdia, Elegy of Sioni, I, Cosmic Liturgy, 2014, p. 34.

8. Zviad Gamsakhurdia, Torture of Seconds, Cosmic Liturgy, 2014, p. 36.

9. Zviad Gamsakhurdia, Elegy of Kvabtakhevi, Cosmic Liturgy, 2014, p. 37. 